\title{
2.3 Social Innovation in Condominium Management. The Intermediary Role of Third Sector Organisations in Supporting Low-INCOME HOMEOWNERS
}

\author{
Luz María VERGARA \\ Delft University of Technology
}

\section{Introduction}

This paper is part of the $\mathrm{PhD}$ project 'Managing Social Condominiums"', which focuses on the role of third sector organisations in supporting Chilean low-income homeowners in condominium management. Understanding the relevance of external action to improve management processes among vulnerable households, this paper presents the intermediary role of the third sector as a vehicle for social innovation. It analyses and discusses the participation and roles of the third sector in housing and condominium management activities by using a database of international case studies. The results reveal different ways of participation of the third sector through public programmes, single interventions and specialised organisations and distinguishes between implementer and catalyst roles of the third sector.

\section{Background}

A major challenge for low-income homeowners is to provide adequate maintenance for their homes in order to ensure that housing value will increase or at least not decrease over time. According to ACQuAYe (2011, p. 20), "without the means to provide maintenance for their homes, low-income homeowners risk not realizing

The PhD is funded by the National Commission for Scientific and Technological Research of Chile (CONICYT) under Grant 72140221. 
the much touted benefits of homeownership; instead they may experience unhealthy living conditions for their families, depreciating value of their homes, instability in their neighbourhoods and inability to sustain the gains in low-income homeownership'.

The case of Chile illustrates the problems of low-income homeownership and the challenges in housing management among households. Chilean housing policies have promoted ownership among vulnerable families during the last thirty years through a neoliberal mechanism of subsidies and credit facilities. Similar to many other Latin American countries, these policies are based on relocation, resettling families from slums to new housing in the outskirts of the city. Despite the success in numbers, this model has entailed new problems with regards to the quality of houses, buildings and neighbourhoods. Significant housing deterioration and dissatisfaction among inhabitants with their houses and neighbourhoods are some of the main problems that have been named (RodríGuez \& Sugranyes, 2004). Other problems are small housing units which have led to crowded living conditions, inability to maintain the houses and common areas in the new dwellings (DuCCI, 1997) and spatial segregation due to the concentration of social housing in peripheral urban zones (Brain, Iacobelli, \& Sabatini, 2005).

Within the social housing stock built in this period, social condominiums (affordable condominiums) are the most affected in terms of initial low-quality as well as poor ongoing maintenance and organisational problems (MINVU, 2014b). According to a cadastre conducted by the Ministry of Housing and Urbanism (MINVU, 2014a), 99\% of social condominiums present maintenance problems and either regular (30\%) or bad (69\%) general maintenance index, especially those built between the 1980s and 1990s (Fig. 1). The concept of 'social condominium' was used by the government to define a housing type consisting of medium-rise building apartments of three to four storeys. These buildings contain areas of individual property and areas of common domain, such as the land, the shared facilities and service areas, the structure and the infrastructure of the building or the housing complex (MINVU, 2015).

Whilst in single family dwellings the owner and the family have overall control of the maintenance activities, in the case of condominium tenure the management of the building has to deal with the organisational tension between the individual and the group. This situation creates social and financial connections between the co-owners (YAU, 2013), entailing complex arrangements for collective decision-making to take care of common property areas which are more subject to deterioration (DonOso \& ELSINGA, 2016). Therefore, the administration of condominiums requires the active and leading participation of households to keep the dwellings and buildings in optimal conditions. Nevertheless, in the context of low-income homeownership, co-owners have to deal with financial and social constraints that may diminish their capacity to take collective care of the building maintenance (CAVALHEIRO \& ABIKO, 2015). 
Figure 1: Current situation of social condominiums built during the $1990 \mathrm{~s}$. Quilicura, Santiago, Chile. (Photo: Vergara, 2016)

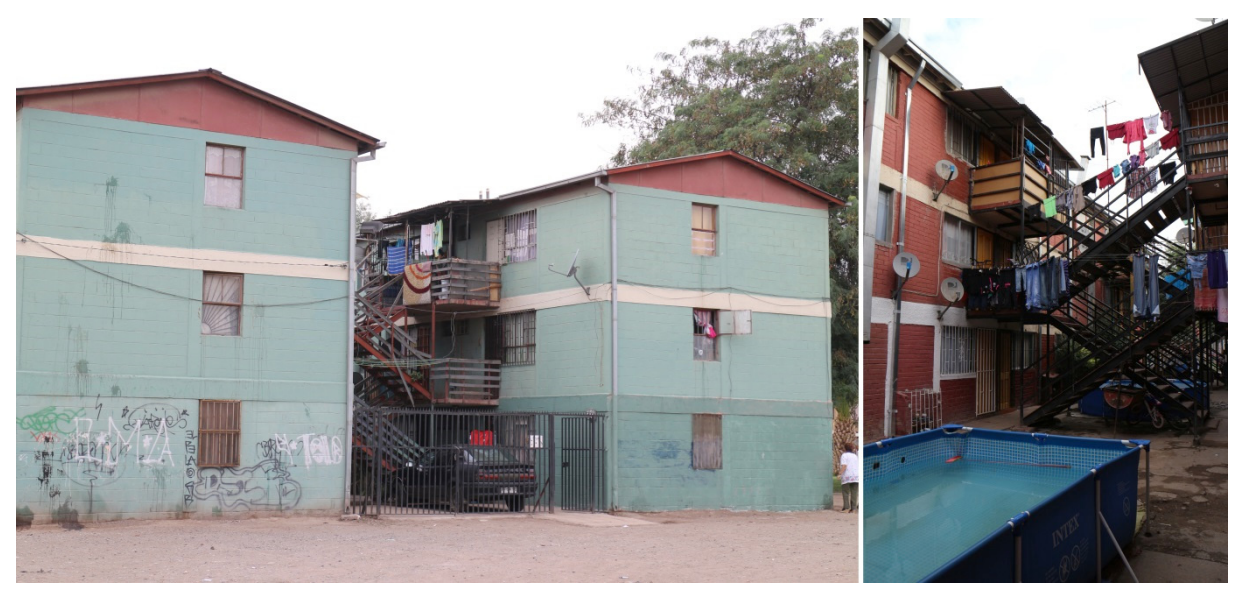

In Chile, the problem of low-income homeownership and condominium maintenance is characterised by two main elements, firstly, by a lack of preventive approaches to housing maintenance. Low-income families that invest in their dwellings maintain them according to their available resources and most urgent needs with do-it-yourself solutions. These solutions often result in informal and precarious enlargements which endanger the safety conditions of the buildings. Similarly, governmental action through subsidy programmes represents reactive housing policies that enable upgrades of dwellings and buildings when they have reached high levels of deterioration. However, apart from the administrative organisation of condominiums, current governmental programmes do not offer any type of mechanism to uphold the investments and to ensure that proper maintenance will be carried out in the future.

Secondly, housing management is an undeveloped field in terms of processes, actors and organisational structures. The government is aware of the challenges that low-income homeownership entails. Nevertheless, management processes are not part of current housing policies or institutional structures. One of the main drawbacks is the lack of actors willing to provide housing management services for low-income groups. While the private sector does not perceive this part of the demand as a profitable target group, local governments often lack the capacity for financial and human resources. On the other hand, the irruption of new actors such as third sector or civil society organisations have increased in the last decades in housing and neighbourhood activities, and some practices have proven to be a competitive alternative to profit organisations. Although they have made contributions in terms of social innovation and social economy (Chile, 2015; Gatica, 2011; Pizarro, 2010), the role of these new actors is still vague and unknown, especially regarding their performance in specific fields such as housing management. 


\section{Potential solutions: The external action of third sector organisations}

The lack of institutional support for long-term housing maintenance as well as the inability of homeowners to access private support makes it necessary to develop alternative management approaches to maintain and manage social condominiums. This also requires the irruption of new actors that fill a current service gap regarding condominium interventions. Furthermore, additional support either from the government, the third sector or the private sector is needed to cope with the financial and knowledge gap faced by the most vulnerable groups.

One possible solution is the use of external action to stimulate and catalyse these communities. Several scholars have pointed out the relevance of intermediary organisations to support low-income and vulnerable groups to enhance their capacities (LeE, 1998), promote social capital (LANG \& Novy, 2014) and facilitate the access to opportunities, resources and skills. Third sector organisations which are not part of the private sector or the public sector have been recognised as relevant intermediaries in the provision of services to deprived sectors and have been historically associated with social innovation, entrepreneurial dynamics and the invention of a new type of services to take up contemporary challenges (DEFourny \& NysSENS, 2014).

Therefore, third sector organisations and their role as intermediaries are explored as part of the solutions to support homeowners in condominium improvement and management. This paper is part of the ongoing PhD project 'Managing Social Condominiums', the main goal of which is to show the possibilities and constraints of third sector organisations in supporting homeowners in the management of Chilean social condominiums and to define guidelines for an alternative role. This paper focuses on the theoretical definition of the role of third sector organisations in condominium management and discusses their current contribution to social innovation as intermediary agents in vulnerable contexts. It aims to answer the following questions: How do third sector organisations contribute to social innovation in the field of housing and condominium management? And what specific activities define the current role of third sector organisations in condominium management? The paper begins with the theoretical definition of the third sector as a vehicle for social innovation and the dimensions of condominium management. Second, it presents an international database of third sector practices related to housing management. Third, it discusses the current role of the third sector in terms of type of practices and intermediation. 


\section{Third sector and social innovation in condominium management}

\section{The intermediary role of the third sector in vulnerable contexts from the perspective of social innovation}

Social innovation, in which a novel idea is carried out to provide a social value, is one of the possible paths to follow to offer a solution to societal needs. The concept of social innovation has become extremely relevant in the debate of the last decades not only regarding its theoretical construction, but also considering its practical implications. Authors such us Moulert, Czischke and Edwards-Schachter \& Wallace have carried out systematic reviews on its conceptualization. The results have shown an increasing trend in the literature in the last decade (Edwards-Schachter \& Wallace, 2017), a wide variety of understandings across academia, policy and practice (CZISCHKE, 2013) and a multi- and even interdisciplinary notion of this concept (Moulaert, 2011). Despite the variety of definitions, the different concepts of social innovation share core elements in which 'innovation' is understood as the capacity to create and implement novel ideas which are proven to deliver value and 'social' refers to the value expected from this innovation which is related to quality of life, solidarity and well-being (CzIsChKe, 2013).

In the field of community development, social innovation is associated with three main dimensions: content/product, process and empowerment (MOULAERT, MARTINELLI, Swyngedouw, \& Gonzalez, 2005; Tello-Rozas, 2016). Whilst the product is about the satisfaction of unmet human needs not yet or no longer perceived as important by the state or the market, the process is related to changes in social relationships, especially with regards to governance in deprived groups of society. The empowerment dimension is about 'increasing the socio-political capability and the access to resources to enhance rights to satisfaction of human needs and participation' (MOULAERT et al., 2005, p. 1976). In this view, social innovation strongly concerns process innovation, social exclusion and empowerment. Therefore, the role of institutions, namely organisations, regulations, laws and agents is relevant in the creation of new relations or collaborations in deprived communities, especially in terms of empowerment and process. Given the relevance of the institutions as vehicles of social innovation, this paper focuses on the organisations that create and implement social innovation at a local level, and especially on how third sector organisations are relevant in supporting deprived communities.

The third sector (i.e. civil society, NGOs, grassroots movements, the non-profit sector) has been historically associated with social innovation. The debate in the 1970's and 80's described the international expansion of non-profit organisations, third sector 
initiatives and social movements as providers of social innovation in the social economy. The most recent debate has shown the evolution of the participation of the third sector through new grassroots movements and the emergence of hybrid organisations in the context of collective processes and cross-partnerships (EDWARDS-SCHACHTER \& WALLACE, 2017). Considering their intermediate position between the state, market and society, third sector organisations are also relevant in overcoming market and state failures and proposing social change in both emerging and developing countries (TELLo-RozAs, 2016).

Figure 2: Third sector organisations situated between the state, the market and the community. Based on Brandsen T., van de Donk W., \& Putters K. (2005).

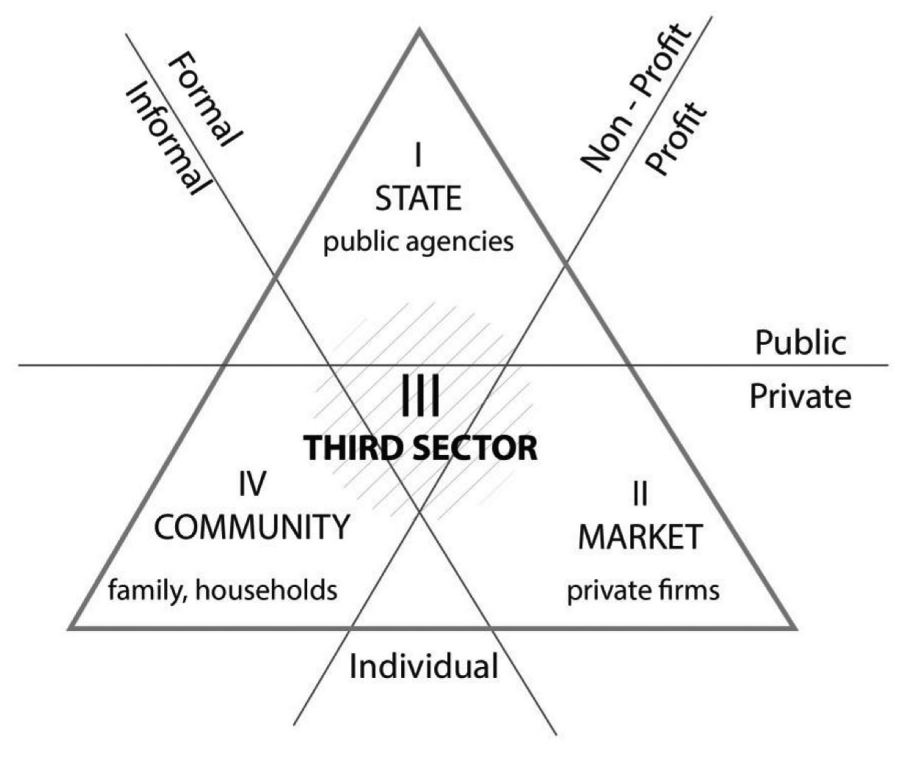

adapted from Brandsen, T., van de Donk, W., \& Putters, K. (2005)

An added value of the work of third sector organisations in vulnerable contexts is their intermediary role. LEE (1998) pointed out the relevance of intermediaries in supporting low-income groups when the community capacity has reached the limit of what they can achieve by themselves. In the field of community development 'to intermediate' is defined by scholars as acting for, between and among entities, considering the future well-being of communities and individuals (Liou \& STROH, 1998). 
Several authors have referred to the relevance of intermediaries in building communities' capacity and contributing to social capital. Following the definition of Putnam, Leonardi, and Nanetti (1994), scholars have defined the role in bonding and bridging social capital to enhance the cohesiveness of communities (AGGER \& JENSEN, 2015; LANG \& Novy, 2014). Intermediaries can also play a role in the creation of strategic vertical linkages between the community with powerful actors at other scales. Such 'vertical' intermediaries contribute to the access of communities to key decisionmaking processes (LANG \& Novy, 2014), increasing their access to available resources and information as well as promoting institutional trust between communities and authorities (AGGER \& JENSEN, 2015).

An interesting approach to identify how the intermediary role is performed in terms of strategies and activities was provided by LEwIS (2002) in the context of nongovernmental development organisations. He suggested a classificatory framework which proposes three main overlapping sets of activities and roles: implementers, catalysts and partners. Whilst the 'implementer' role refers to organisations that mobilise resources to provide goods and services, the 'catalyst' role refers to organisations that inspire, facilitate or contribute to developmental change among the community (i.e. grassroots organising or empowerment-based approaches). The 'partner' refers to organisations that work with other institutions such as the government, with donors and the private sector on joint activities. Each classification represents strategies that define the focus of the intermediation and the approach to solve complex problems.

On balance, third sector organisations acting as intermediaries have the potential to generate social innovation among deprived communities. Following the definition of social innovation from the community development approach, the role of third sector organisations can contribute to improving a community's wellbeing by satisfying unmet needs, fostering new processes or empowering the community. Even though there is increasing literature on third sector and social innovation, more information is needed about the processes in order to understand the mechanism and practices used by these organisations to produce social innovation (Tello-Rozas, 2016). Keeping in mind the intrinsic value of the intermediate position of the third sector, we will focus on the analysis of practices of organisations that perform in the field of housing management.

\section{Condominium management}

In order to analyse the contribution of third sector organisations, we identify the condominium as the unit of analysis and collective management as the focus of the intervention. Combining elements from organisational management theory (GRUIS, TSENKova \& NiEBOER, 2009), the common property management framework (DoNOSO \& 
Elsinga, 2016; Ostrom, 1990) and the social vulnerability framework (Moser, 1998), housing management is defined as a multidimensional process that is pulled by three main interrelated dimensions: the technical, the organisational and the sociocultural dimension. The condominium is understood as a common property resource that is collectively managed by co-owners with the purpose to maintain the quality of their built environment.

The technical dimension considers the execution of actions to ensure the correct physical performance of the building (repair, improvement or maintenance). The organisational dimension refers to the coordination of human and financial resources required to conduct technical and administrative activities under a specific institutional framework and governance structure. Finally, the sociocultural dimension refers to the behaviour of co-owners as individuals and as a group with respect to their built environment. This multidimensional framework will be used to describe and understand the impact of third sector organisations in condominium management activities. Fig. 3 shows the dimensions and their elements.

Figure 3: Housing management dimensions and elements for condominium tenure.

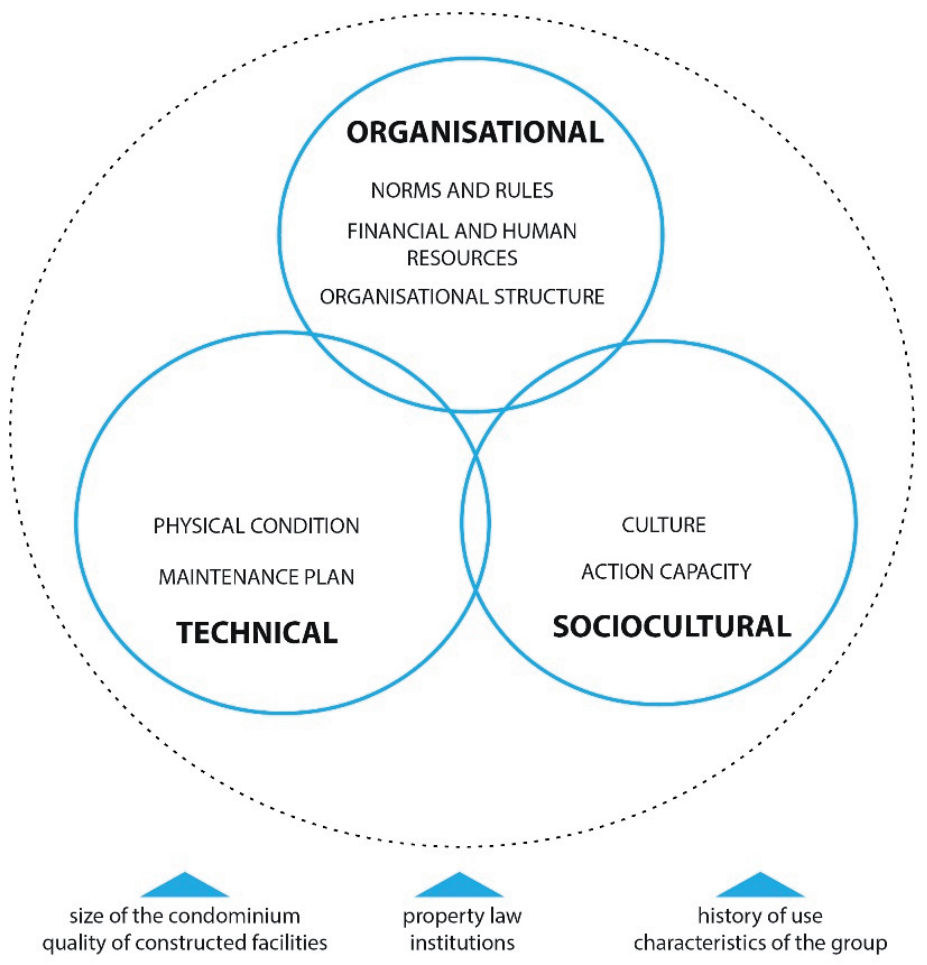




\section{Third sector and housing management: A database of international experiences}

Regarding housing management, the role of the third sector has been extensively analysed in the area of social (rental) housing but scarcely mentioned in the owneroccupied sector. Considering the already mentioned potential of third sector organisations as intermediaries in vulnerable contexts, we selected a group of experiences in which the third sector has contributed to improving management practices among lowincome homeowners. The analysis of these experiences will provide insights into how this role is performed in practice. The focus will be on condominium management activities identifying third sector organisations which contribute to improving technical, organisational or sociocultural dimensions of housing management.

The role of the third sector will be discussed from two perspectives. The first one looks at how the third sector participates in housing management and distinguishing between specialized organisations, public programmes and single interventions. The second analysis is carried out from the intermediation perspective and aims at understanding the third sector as implementer or catalyst in condominium management practices.

\section{Methods for the selection of practices}

The research approach to building the database used primary and secondary sources of data collecting. While the first one consisted of face-to-face and Skype interviews with key informants and representatives of third sector organisations, the second one consisted of a literature review and search queries in online journal databases. The core of the activities was carried out during 2015 and 2016, and a second review was performed in 2017 to update the general database.

The database comprises international case studies from Latin America and Europe. The search for cases in the Latin American context aimed to identify experiences closer to the local and cultural conditions in Chile. On the other hand, the search for European cases aimed to expand the approaches for tackling housing management problems, especially regarding cross-sector partnership, the longer tradition of third sector organisations and the accumulated experience in social housing management. The following criteria were considered for selecting the practices:

- The organisation aims to improve housing management conditions, addresses one, two or three dimensions of housing management (organisational, technical or sociocultural) and develops activities that directly or indirectly impact the built environment. 
- Though our intervention focus lies on condominiums, we also searched for neighbourhood or single-family interventions which incorporate collective management approaches.

- The target group are vulnerable homeowners who face financial or social constraints on developing housing management activities.

- The intervention is carried out from a socially innovative perspective. We use the features identified by Czischke (2013) for social innovation practices in housing. These common features were identified through interviewing European practitioners working in the housing field. Therefore, the intervention should consider at least one of following approaches: any degree of user involvement, user perspective, cross-sector collaboration, multidimensional approach to face complex problems and streamlining (systematisation, monitoring and evaluation of activities and processes).

Table 1: Database of international cases of third sector participation in housing management.

\begin{tabular}{|c|c|c|c|c|c|}
\hline \multirow[b]{2}{*}{ \# } & \multirow{2}{*}{$\begin{array}{c}\text { INTER- } \\
\text { MEDIARY } \\
\text { ORGANISA- } \\
\text { TIONS }\end{array}$} & \multirow{2}{*}{ MAIN GOAL } & \multirow{2}{*}{$\begin{array}{l}\text { TYPE OF } \\
\text { INTER- } \\
\text { MEDIARY }\end{array}$} & \multicolumn{2}{|c|}{ INTERMEDIARY ROLES } \\
\hline & & & & $\begin{array}{l}\text { IMPLE- } \\
\text { MENTER }\end{array}$ & CATALYST \\
\hline 1 & $\begin{array}{l}\text { Fundacion } \\
\text { Bienestar } \\
\text { (Ecuador) }\end{array}$ & $\begin{array}{l}\text { Co-support the con- } \\
\text { struction of sustainable } \\
\text { communities } \\
\text { by creating and } \\
\text { promoting good } \\
\text { coexistence practices } \\
\text { in residential buildings } \\
\text { and neighbourhoods. }\end{array}$ & $\begin{array}{l}\text { Specialised } \\
\text { organisation } \\
\text { (founda- } \\
\text { tion/OSFL) }\end{array}$ & $(-)$ & $\begin{array}{l}\text { - Support to vulnerable families } \\
\text { transitioning into new social } \\
\text { housing projects. } \\
\text { - Workshops about positive } \\
\text { coexistence, community } \\
\text { organisation, formation of } \\
\text { leaders, conflict resolution and } \\
\text { co-responsibility considering } \\
\text { duties and rights. }\end{array}$ \\
\hline 2 & $\begin{array}{l}\text { Habitat para } \\
\text { la Humanidad } \\
\text { Chile } \\
\text { (Chile) }\end{array}$ & $\begin{array}{l}\text { Promote better living } \\
\text { conditions to families } \\
\text { and communities } \\
\text { in three main areas: } \\
\text { social management, } \\
\text { technical assistance } \\
\text { and disaster response. }\end{array}$ & $\begin{array}{l}\text { Specialised } \\
\text { organisation } \\
\text { (founda- } \\
\text { tion) }\end{array}$ & $\begin{array}{l}\text { - Design and } \\
\text { construction } \\
\text { of condo- } \\
\text { minium } \\
\text { improvement } \\
\text { projects. }\end{array}$ & $\begin{array}{l}\text { - Support for organising } \\
\text { condominium administrations } \\
\text { - Formation of community } \\
\text { leaders } \\
\text { - Educational programmes } \\
\text { focusing on maintenance } \\
\text { practices, good use of the } \\
\text { built environment and water } \\
\text { management, among others. }\end{array}$ \\
\hline 3 & $\begin{array}{l}\text { HOME: } \\
\text { Empowering } \\
\text { grass-root } \\
\text { homeowners } \\
\text { associations } \\
\text { (Azerbaijan, } \\
\text { Belarus, } \\
\text { Georgia, } \\
\text { Moldova and } \\
\text { Ukraine) }\end{array}$ & $\begin{array}{l}\text { Support residents in } \\
\text { organising an effective } \\
\text { administration of } \\
\text { their apartment } \\
\text { buildings through the } \\
\text { establishment of } 10 \\
\text { Technical Advisory } \\
\text { Centres (TACs) }\end{array}$ & $\begin{array}{l}\text { Public } \\
\text { programme } \\
(\mathrm{NGO})\end{array}$ & $(-)$ & $\begin{array}{l}\text { - Increase the knowledge and } \\
\text { awareness of citizens about } \\
\text { their property rights, principles } \\
\text { and activities of homeowners' } \\
\text { associations (HOAs) } \\
\text { - Organize and conduct seminars } \\
\text { and trainings on topics related } \\
\text { to HOAs } \\
\text { - Support the organization, } \\
\text { implementation and participation } \\
\text { of HOA meetings } \\
\text { - Individual consulting and } \\
\text { training of local residents }\end{array}$ \\
\hline
\end{tabular}




\begin{tabular}{|c|c|c|c|c|c|}
\hline 4 & $\begin{array}{l}\text { La Bezindalla } \\
\text { (Spain) }\end{array}$ & $\begin{array}{l}\text { Improve the } \\
\text { relationships between } \\
\text { groups, communities } \\
\text { and neighbourhoods } \\
\text { and contribute to } \\
\text { social transformation } \\
\text { and independent } \\
\text { communities }\end{array}$ & $\begin{array}{l}\text { Specialised } \\
\text { organisation } \\
\text { (co- } \\
\text { operative) }\end{array}$ & $(-)$ & $\begin{array}{l}\text { - Mediation services for home- } \\
\text { owners' associations } \\
\text { - Support and mediation for } \\
\text { conflict resolution in condo- } \\
\text { miniums } \\
\text { - Organisational advice for } \\
\text { community organisations } \\
\text { - Participatory education } \\
\text { processes (information about } \\
\text { condominium management, } \\
\text { communication skills) }\end{array}$ \\
\hline 5 & $\begin{array}{l}\text { Oud- } \\
\text { Mathenesse } \\
\text {-Woonbron } \\
\text { (The } \\
\text { Netherlands) }\end{array}$ & $\begin{array}{l}\text { Experimental project } \\
\text { to support HOAs in } \\
\text { the maintenance and } \\
\text { administration of their } \\
\text { buildings as co-owners }\end{array}$ & $\begin{array}{l}\text { Single inter- } \\
\text { vention } \\
\text { (housing } \\
\text { association) }\end{array}$ & $\begin{array}{l}\text { - The organi- } \\
\text { sation bought } \\
\text { dwellings in } \\
\text { the buil-ding to } \\
\text { be part of the } \\
\text { homeowners' } \\
\text { associations. } \\
\text { - Technical } \\
\text { inspection of } \\
\text { the building } \\
\text { and providing } \\
\text { advice on } \\
\text { maintenance } \\
\text { plans. }\end{array}$ & $\begin{array}{l}\text { - Participate in HOA meetings in } \\
\text { a horizontal position, influencing } \\
\text { and supporting decisions from } \\
\text { inside as part of the community. }\end{array}$ \\
\hline 6 & $\begin{array}{l}\text { Proyecto } \\
\text { Propio (Chile) }\end{array}$ & $\begin{array}{l}\text { Enable access to } \\
\text { knowledge and to } \\
\text { mechanisms and } \\
\text { processes that help a } \\
\text { community develop its } \\
\text { own projects. }\end{array}$ & $\begin{array}{l}\text { Specialised } \\
\text { organisation } \\
\text { (social } \\
\text { enterprise) }\end{array}$ & $\begin{array}{l}\text { - Design and } \\
\text { construction of } \\
\text { condomi-nium } \\
\text { impro-vement } \\
\text { projects } \\
\text { including } \\
\text { participatory } \\
\text { methods. }\end{array}$ & $\begin{array}{l}\text { - Support for organising } \\
\text { condominium administrations } \\
\text { and leadership } \\
\text { - Training for condominium } \\
\text { administrative committees } \\
\text { - Provide information about } \\
\text { condominium tenure and } \\
\text { maintenance practices for co- } \\
\text { owners }\end{array}$ \\
\hline 7 & $\begin{array}{l}\text { Servicio de } \\
\text { Dinamizacion } \\
\text { Vecinal (SDV) } \\
\text { (Spain) }\end{array}$ & $\begin{array}{l}\text { Contribute to a } \\
\text { positive coexistence in } \\
\text { neighborhoods in order } \\
\text { to establish active, } \\
\text { independent and self- } \\
\text { organised communities }\end{array}$ & $\begin{array}{l}\text { Public } \\
\text { programme } \\
(\mathrm{CBO})\end{array}$ & $(-)$ & $\begin{array}{l}\text { - Improve capacity building } \\
\text { of the community and } \\
\text { neighbourhood associations. } \\
\text { - Promote participation in } \\
\text { neighbourhood / condominium } \\
\text { activities. } \\
\text { - Provide tools for managing } \\
\text { conflicts between neighbours. }\end{array}$ \\
\hline 8 & $\begin{array}{l}\text { Urbanismo } \\
\text { Social } \\
\text { (Chile) }\end{array}$ & $\begin{array}{l}\text { Strengthen } \\
\text { neighbourhoods' } \\
\text { identities, autonomy } \\
\text { and social integration }\end{array}$ & $\begin{array}{l}\text { Specialised } \\
\text { organisa- } \\
\text { tion } \\
\text { (founda- } \\
\text { tion) }\end{array}$ & $\begin{array}{l}\text { - Design and } \\
\text { construction of } \\
\text { condominium } \\
\text { improvement } \\
\text { projects as } \\
\text { part of a } \\
\text { neighbourhood } \\
\text { strategy. } \\
\end{array}$ & $\begin{array}{l}\text { - Support for organising } \\
\text { condominium administrations } \\
\text { and leadership } \\
\text { - Provide information about } \\
\text { condominium tenure and } \\
\text { maintenance practices }\end{array}$ \\
\hline 9 & $\begin{array}{l}\text { VVE-010 } \\
\text { (The } \\
\text { Netherlands) }\end{array}$ & $\begin{array}{l}\text { Improve maintenance } \\
\text { practices among } \\
\text { homeowners' } \\
\text { associations } \\
\text { by providing } \\
\text { administrative } \\
\text { information and } \\
\text { technical advice. }\end{array}$ & $\begin{array}{l}\text { Public } \\
\text { programme } \\
\text { (foundation) }\end{array}$ & $\begin{array}{l}\text { - Provide } \\
\text { affordable } \\
\text { services for } \\
\text { condominium } \\
\text { administration } \\
\text { - Develop a } \\
\text { maintenance } \\
\text { plan based on } \\
\text { a technical } \\
\text { inspection of } \\
\text { the building }\end{array}$ & $\begin{array}{l}\text { - Activate sleeping VVes } \\
\text { (homeowners' associations). } \\
\text { - Provide legal information about } \\
\text { duties and responsibilities related } \\
\text { to condominium tenure. } \\
\text { - Show incentives to facilitate } \\
\text { the participation of VVEs in the } \\
\text { programme. Enforce the law if } \\
\text { incentives are not enough. } \\
\text { - Facilitate access to professional } \\
\text { advice and financial support. }\end{array}$ \\
\hline
\end{tabular}




\footnotetext{
* Other cases in the extended database: Casematte (specialised organisation, Italy), Comunitaria (specialised organisation, Spain), Almada neighbourhood (single intervention, Portugal), The Flat Owners Society "DRAUDZIBA" (specialised organisation, Slovakia), Arquitectos de la Comunidad Uruguay (specialised organisation, Uruguay), Celobert (specialised organisation, Spain), Estudio Livingston - Arquitecto (specialised organisation, Argentina), ETP Slovakia, microloan program (public programme, Slovakia), Fundacion Pro Vivienda Social (specialised organisation, Argentina), IGLOO France (specialised organisation, France), Junto al Barrio (specialised organisation, Chile), Den Haag Balie (public programme, The Netherlands), Lourdes Renove (single intervention, Spain).
}

\section{The presence of the third sector in housing management: Specialised organisations, public programmes and single interventions}

The database comprises 22 cases out of which 9 'core cases' were selected for further description and analysis (Tab. 1). The cases show different ways of how the third sector is involved in housing management activities. It is possible to identify three main types of participation of the third sector in condominium management: specialised organisations, public programmes and single interventions.

The first type, 'specialised organisations', comprises third sector entities that actively work in condominium management as their main or secondary activity. This includes organisations working in areas of maintenance, administration, community development, training or physical improvement. Within the organisations, we could identify social enterprises (Proyecto Propio), foundations (Urbanismo Social, Junto al Barrio, Fundacion Bienestar), private organisations with limited profit (Arquitectos de la comunidad), cooperatives (La Bezindalla, Comunitaria) and NGOs (Habitat para la Humanidad).

The second group of initiatives, 'public programmes', considers public administration programmes or policies coordinated either by the central government, local governments or international agencies. They tend to be temporary initiatives created to tackle specific problems. They are focused on improving condominiums and neighbourhood conditions with technical, organisational and/or social interventions. These programmes consider a third sector intermediary for their implementation, which can be either a technical team of professionals, specialised organisations hired for this purpose or transitory public-private partnerships.

One example is VVE-010, a foundation focused on tackling neglected maintenance in residential buildings in Rotterdam in the Netherlands that provides assistance to homeowners' associations. The foundation is sponsored by the Municipality of Rotterdam 
and it is embedded in a national plan for deprived neighbourhoods. Another example is 'Servicios de Dinamizacion Vecinal' (Services of Neighbourhood Activation), which is a bottom-up initiative of neighbourhood associations in Madrid which promotes the development of vulnerable neighbourhoods and helps improve collective participation. The programme is coordinated by the FRAVM (Regional Federation of Neighbourhood Associations) and funded by the local government.

The third group, 'single interventions', comprises specific projects in which third sector organisations have actively participated. They tend to be one-time initiatives but are nevertheless successful examples with the potential of being replicated. One of these examples is an experimental project implemented by the housing association Woonbron in the neighbourhood of Oud Mathenesse in Rotterdam. The project, considered an 'experiment' by the organization, acquired apartment units in a condominium with poor maintenance in order to participate as a co-owner in the meetings and have an impact on maintenance practices from a horizontal position with respect to the community.

The database shows that the presence of the third sector in housing management activities is not homogeneous and, on the contrary, it has diverse participation and various levels of institutionalization. While private specialized organisations pursue their own agenda in which housing management activities can be either the leading or secondary activity, public programmes tackle specific needs in which the third sector is part of a network of cooperations that align common goals with public institutions. In the case of single interventions, the needs and solutions are more specific and thus they respond to one particular moment. Single interventions can also be seen as a test for the implementation of future programmes or as explorations of new areas of intervention in third sector organisations.

\section{Intermediation: Implementers or catalysts?}

A second analysis of the database is carried out concerning the intermediary role and the understanding of third sector organisations based on their practices. Using LEWIS's definition we identify two main sets of overlapping roles and activities: implementers and catalysts (LEwIs, 2002) ${ }^{2}$. The roles are adapted to condominium management, in which the condominium is the unit of the analysis and the collective management is the focus of the intervention. In this version, third sector organisations intervene in a condominium, which is compounded by a physical built environment and by a community of co-

\footnotetext{
2 In this analysis, we excluded the role of 'partner' because it aims at improving the organisation's capacities and therefore is not directly related to solving the problem of the condominium. The role of partner is understood as a means to improve an organisation's resources and skills to be either an implementer or a catalyst.
} 
owners and households. Following the framework of LEWIS, implementers as providers of goods and services focus mainly on improving the physical conditions of the built environment, involving all services and activities that aim directly at the buildings, collective areas and/or the dwellings. The catalyst role, as facilitator of developmental change, focuses on the community and comprises practises that contribute to improving the community's capacity within condominium management.

The nine analysed cases showed that implementers contribute directly either to technical or to organisational dimensions of condominium management. In the technical dimension, the main activities are improving the physical conditions of the building through repairs and refurbishment projects, designing and constructing architecture projects within the condominium and providing professional maintenance advice. In the organisational dimension, the activities identified are providing affordable services for condominium maintenance and mobilising financial resources for maintenance activities. On the other hand, catalyst roles aim at sociocultural and organisational dimensions of housing management. The main activities identified are providing information about housing maintenance and condominium tenure in terms of laws, regulations and administration, providing skills to households and homeowners' associations through workshops and training activities, connecting the community with external institutions that enable access to resources, and offering support or intermediation for conflict resolution related to the use of the common areas.

While it was possible to identify organisations that acted purely as catalysts, there were no cases that acted purely as implementers. This can be understood as an outcome of the requirements posed by the problem which is reflected in the selection of the practices. The problem of neglected maintenance in vulnerable contexts is directly related to the lack of organisational structures and action capacity of co-owners, and therefore the presence of organisational and sociocultural perspectives is relevant in the interventions.

For instance, the organisation Proyecto Propio adopts an implementer role by carrying out the design and construction of condominium improvement projects for the common domain areas (i.e, façade refurbishment, reinforcement of damaged structures, projects for upgrading the common areas of condominiums such as halls and central courtyards). To do so, the organisation applies for governmental subsidies and works on a project-based approach. During the design process they use participatory tools in order to customize the projects according to household needs and to engage the co-owners in the decisions related to their properties. Although the implementer role is predominant, the organisation also acts as a catalyst by supporting co-owners to activate their organisational structures and by promoting the emergence of leaders in the condominiums. The physical improvement of the condominium is a milestone for the community and it is used by the organisation as a means to indirectly improve future maintenance practices. This approach to the condominium and the project-based model is also common among other Chilean third sector organisations such as Habitat para la Humanidad Chile or Urbanismo Social. 
Another example of an implementer role is the foundation VVE-010, which is the third sector coordinator of the programme initiated by the municipality of Rotterdam. After a technical inspection of the condominium, the foundation proposes to the homeowners' association a long-term maintenance plan which will be used as a roadmap for the next 15 years. The plan establishes short-term actions (for the first five years) that are mandatory for accomplishing the minimum standards of the Dutch housing act as well as long-term actions required for the future. Furthermore, VVE-010 offers affordable services for condominium administration for those communities that cannot afford market prices. This service is temporary and lasts until the communities are ready to hire a private administrator. Along with the technical support, VVE-010 seeks to improve maintenance practices in the future. In this regard, they provide information about duties and rights related to condominium tenure. Furthermore, they rely on third party executers to activate 'sleeping' homeowners' associations (VVEs).

On the other hand, it is possible to identify initiatives that aim their main activities at the community, expecting that the built environment will benefit the community indirectly. One example is the programme HOME. Housing initiative for Eastern Europe: Empowering grass-root homeowners associations. The initiative lead by the German organisation IWO has the main goal to support residents in organising an effective administration of their apartment buildings through the establishment of 10 Technical Advisory Centres (TACs). These centres have the purpose of improving the organisational capacities of homeowners' associations. The initiative is being implemented in Azerbaijan, Belarus, Georgia, Moldova and Ukraine with various local project partners (local governments, NGOs and civil society institutions) carrying out the initiative.

Other examples of catalyst roles are the programme Servicios de Dinamizacion Vecinal and the organisation La Bezindalla, both locatedin Spain. As previously explained, the SDV is a bottom-up initiative of neighbourhood associations with the aim to improve the coexistence in their neighbourhoods. The programme provides an 'activator' in each neighbourhood who supports neighbour associations in dealing with coexistence problems with respect to the communal use of the public space as well as the common areas inside residential buildings. The activator is a professional with a background in community management who acts as an enabler of activities that improve neighbourhood cohesion. La Bezindalla is a cooperative with the main goal of improving community relationships in affordable condominiums by offering mediation services for homeowners' associations and supporting conflict resolution. They also offer educational programmes about living in a condominium as well as design and manage participatory processes with customised activities. Similarly, Fundacion Bienestar in Ecuador is a foundation that supports vulnerable groups in the construction of sustainable communities, especially with regards to coexistence and good practices inside residential buildings.

The analysed cases provide different approaches to condominium management covering the three dimensions (technical, organisational and sociocultural) and their 
respective elements. Although in every case there is one approach that prevails, either regarding the roles or the dimensions, the interventions are all multidimensional and target at least two dimensions of housing management. The condominium is understood as a physical and organisational unit, in which the intervention can aim at one or both dimensions. In this regard, we can identify two polar approaches: practices in which the implementer role prevails and which intervene directly in the built environment and therefore in the technical dimension (i.e., maintenance plan and physical conditions) and certain organisational elements (i.e., human and financial resources for administration). The project and the positive outcome of the aesthetical upgrading is used as a means to try and influence better maintenance practices in the future. On the contrary, in practices where the catalyst role prevails, the intervention targets the community and therefore the sociocultural (i.e., action capacity and maintenance culture) and organisational dimensions (i.e., organisational structure, norms and rules). In this case, the activities are related to strengthening leaderships in order to consolidate organisational structures and inspire better practices among homeowners related to maintenance and community life. The expectation is that providing tools and skills to households will result in better quality in the built environment in the future.

\section{Conclusions}

This paper is part of the $\mathrm{PhD}$ project 'Managing Social Condominiums', the main goal of which is to show the possibilities and constraints of third sector organisations in supporting homeowners in the management of Chilean affordable condominiums. Within the research project, this paper focused on the general role of third sector organisations in housing management from the perspective of social innovation.

Third sector organisations are recognised as intermediaries that support deprived communities when their capacity has reached its limit or their needs have not been fulfilled either by the state or the private sector. As intermediaries, third sector organisations mobilise goods and services but also contribute to improve access to available resources or to key decision-making processes at different spatial levels. The analysis of 9 cases of third sector intermediaries provided insights into the practices of these organisations and the actual strategies employed in deprived communities by addressing the content dimension but also the dimensions of process and empowerment.

In order to characterise the practices of third sector organisations, the case studies were analysed following two perspectives: the ways in which the third sector participates in supporting deprived communities through specialised organisations, public programmes and single interventions, and its intermediary role as implementer and/or catalyst. On the one hand, third sector organisations showed different forms of participation ranging from private organisations with housing management as part of 
their own social agenda, explorative experiences and programmes in which third sector entities are coordinators or executers with common goals for a public-private agenda.

On the other hand, the recognition of implementer and catalyst roles (LEwIS, 2002) made it possible to understand the dynamics of the third sector as an intermediary between the communities and the context by identifying the focus of their approach towards housing management and specifically regarding condominium tenure. In most of the cases, the complexities of disadvantaged contexts required both approaches of targeting the community as well as the built environment. This is also reflected in a multidimensional perspective for dealing with management problems that is aimed at at least two dimensions of housing management. Considering the relevance of sociocultural and organisational elements in the intervention, a working definition of social innovation in condominium management should be related to process and empowerment dimensions, in which the intermediation has the goal to improve the capacity of communities to self-organise and coordinate to ensure proper management in the long term.

This paper has contributed to the discussion of the role of the third sector in disadvantaged contexts and especially in the field of condominium management. While the construction and analysis of the database have provided more information about the way in which the third sector performs as an intermediary, contextual and in-depth case study analyses are needed to understand and measure these interventions in relation to institutional and cultural characteristics of the context in which the interventions are embedded.

\section{References}

Agger A., \& Jensen J. O. (2015), Area-based Initiatives - And Their Work in Bonding, Bridging and Linking Social Capital. European Planning Studies 23(10), pp. 2045-2061. DOI: $10.1080 / 09654313.2014 .998172$

Brain I., Iacobelli A., \& Sabatini F. (2005), Calidad y Valor de la Vivienda Social: Un problema de localización y Barrio (pp. 20).

Cavalheiro D.D., \& Aвiкo A. (2015), Evaluating slum (favela) resettlements: The case of the Serra do Mar Project, Sao Paulo, Brazil. Habitat International 49, pp. 340-348. DOI: 10.1016/j.habitatint.2015.05.014

Chile G. D. (2015), Panorama y proyecciones de la economía social y cooperativa en Chile. Santiago, Chile, Gobierno de Chile.

Czischke D. (2013), Social Innovation in Housing: Learning from practice across Europe.

Defourny J., \& Nyssens M. (2014), Social innovation, social economy and social enterprise: what can the European debate tell us? In: Moulaert F., MacCallum D., Mehmood A., \& Hamdouch A. (eds.), The international handbook on social innovation: collective action, social. Cheltenham, Edward Elgar Publishing Limited. 
Donoso R. E., \& Elsinga M. (2016), Management of low-income condominiums in Bogotá and Quito: the balance between property law and self-organisation. International Journal of Housing Policy 18(2), pp. 1-23. DOI: 10.1080/14616718.2016.1248608

Ducci M.E. (1997), Chile: el lado obscuro de una política de vivienda exitosa. EURE (Santiago) 23(69), pp. 99-115.

Edwards-Schachter M., \& Wallace M. L. (2017), 'Shaken, but not stirred': Sixty years of defining social innovation. Technological Forecasting and Social Change 119, pp. 64-79. DOI: $10.1016 /$ j.techfore.2017.03.012

Gatica S. (2011), Emprendimiento e Innovación Social: construyendo una agenda pública para Chile. http://www.superacionpobreza.cl/wp-content/uploads/2014/03/20111227174334. pdf

Gruis V., Tsenkova S., \& Nieboer N. (2009), Management of privatised housing: international policies \& practice. Chichester, Blackwell Publishing Ltd.

Lang R., \& Novy A. (2014), Cooperative Housing and Social Cohesion: The Role of Linking Social Capital. European Planning Studies 22(8), pp. 1744-1764. DOI: $10.1080 / 09654313.2013 .800025$

LeE Y.S.F. (1998), Intermediary institutions, community organizations, and urban environmental management: the case of three Bangkok slums. World Development 26(6), pp. 993-1011. DOI: $10.1016 / \mathrm{S} 0305-750 \mathrm{X}(98) 00034-5$

Lewis D. (2002), The Management of Non-governmental Development Organizations: An Introduction. David Lewis. London: Routledge.

Liou Y.T., \& Sтroh R.C. (1998), Community development intermediary systems in the United States: Origins, evolution, and functions. Housing Policy Debate 9(3), pp. 575-594.

MINVU. (2014a). Vivienda Social en Copropiedad. Catastro Nacional de Condominios Sociales. Santiago de Chile: Ministerio de Vivienda y Urbanismo.

MINVU. (2014b). Vivienda Social en Copropiedad. Memoria de Tipologías de Condominios Sociales. Santiago de Chile: Ministerio de Vivienda y Urbanismo.

MINVU. (2015). Ley 19.537 de Copropiedad Inmobiliaria (2015).

Moser C.O.N. (1998), The asset vulnerability framework: Reassessing urban poverty reduction strategies. World Development 26(1), pp. 1-19. DOI: 10.1016/s0305-750x(97)10015-8

Moulaert F. (2011), Social innovation and community development: concepts, theories and challenges. In: Moulaert F., Martinelli F., Swyngedouw E. \& González S. (eds.), Can neighbourhoods save the city? Community development and social innovation. London, Routledge.

Moulaert F., Martinelli F., Swyngedouw E., \& Gonzalez S. (2005), Towards alternative model(s) of local innovation. Urban Studies 42(11), pp. 1969-1990. DOI: 10.1080/ 00420980500279893

Ostrom E. (1990), Governing the Commons. The Evolution of Institutions for Collective Action. Cambridge, Cambridge University Press.

Pizarro R. (2010), El tercer sector en Chile: las organizaciones de acción social en el ámbito comunal. Universidad de Granada (diss.). http://hera.ugr.es/tesisugr/1893014.pdf

Putnam R.D., Leonardi R., \& Nanetti R. Y. (1994), Making Democracy Work: Civic Traditions in Modern Italy. Princeton, NJ, Princeton University Press.

Rodríguez A., \& Sugranyes A. (2004), The housing problem of the "non-homeless". EURE (Santiago) 30(91), pp. 53-65. 
Tello-Rozas S. (2016), Inclusive Innovations Through Social and Solidarity Economy Initiatives: A Process Analysis of a Peruvian Case Study. Voluntas 27(1), pp. 61-85. DOI: 10.1007/ s11266-015-9606-y

YAU Y. (2013), Willingness to Participate in Collective Action: The Case of Multiowned Housing Management. Journal of Urban Affairs 35(2), pp. 153-171. DOI: 10.1111/j.14679906.2012.00621.x

\section{List of Figures and Table}

Figure 1: Current situation of social condominiums built during the 1990s. Quilicura, Santiago, Chile

Figure 2: Third sector organisations between the state, the market and the community. Based on Brandsen T., van de Donk W., \& Putters K. (2005) .88

Figure 3: Housing management dimensions and elements for condominium tenure .90

Table 1: Database of international cases of third sector participation in housing management activities.... 
